\title{
ETIKA PERGAULAN REMAJA DALAM KISAH NABI YUSUS AS (Telaah Tafsir Tarbawi dalam Surat Yusuf Ayat 23-24)
}

\author{
ALI NURDIN \\ Universitas Islam Negeri Syarif Hidayatullah Jakarta \\ Ali010655@yahoo.com
}

\begin{abstract}
ABSTRAK
Salah satu metode yang digunakan untuk menyampaikan pelajaran etika adalah metode cerita. Cerita ini memiliki daya tarik khusus yang mampu mempengaruhi pembacanya menjadi seperti orang-orang yang terkandung dalam cerita. Salah satu kisah yang terkandung dalam Alquran adalah kisah Nabi Yusuf as. yang merupakan salah satu huruf dalam al Qur'an. Dari beberapa episode kehidupan Nabi Yusuf as. ada sebuah kisah di mana dia tergoda oleh seorang wanita yang adalah majikannya sendiri untuk melakukan perzinahan. Tetapi Tuhan menjaga dia, dia menolak undangan wanita itu, jadi pada akhirnya dia harus menanggung risiko dipenjara. Tujuan dari penelitian ini adalah untuk menentukan etika sosial yang terkandung dalam kisah Nabi Joseph; Studi tentang Tafsir Tarbawi surah Yusuf ayat 23-24. Dalam menjawab masalah ini, komposer menggunakan metode Tahlili. Penelitian ini digolongkan sebagai Penelitian Perpustakaan (library research) dengan teknik analisis deskriptif kualitatif dengan mengumpulkan data atau bahan yang berkaitan dengan tema diskusi dan masalah yang diambil dari sumber perpustakaan. Hasil penelitian menunjukkan bahwa etika sosial yang terkandung dalam Sura Yusuf ayat 23-24 adalah mempertahankan pandangan, menutupi alat kelamin, menghindari perzinaan, dan bersikap rendah hati.
\end{abstract}

Kata kunci: Etika Sosial, Remaja, Kisah Nabi Yusuf as.

\begin{abstract}
One method used to convey the ethics lesson is the story method. The story has a special attraction that is able to influence its readers to be like the people contained in the story. One of the stories contained in the Qur'an is the story of the Prophet Yusuf as. which is one of the letters in the Qur'an. From several episodes of the life of the Prophet Yusuf as. there is a story where he was seduced by a woman who was his own employer to commit adultery. But God guarded him, he refused the woman's invitation, so in the end he had to bear the risk of being imprisoned. The purpose of this study was to determine the social ethics contained in the story of the Prophet Joseph; Study of Tafsir Tarbawi surah Yusuf verses 2334. In answering this problem, the composer uses the Tahlili method. This research is classified as Library Research (library research) with qualitative descriptive analysis techniques by collecting data or materials related to the theme of the discussion and issues taken from library sources. The results of the study showed that the social ethics contained in Sura Yusuf verses 23-24 is to maintain a view, cover the genitals, avoid adultery, and have a humble attitude,
\end{abstract}

Keywords: Social Ethics, Youth, The Story of the Prophet Yusuf as. 


\section{A. PENDAHULUAN}

Masa remaja merupakan masa peralihan dari anak-anak untuk menjadi dewasa yang ditandai dengan kebimbangan serta keguncangan emosi dalam hal mencari pegangan hidup, ilmu pengetahuan, masa depan, bahkan dalam hal pasangan. Emosi yang luar biasa adalah salah satu bahaya masa remaja. Itu karena dia mengubah remaja menjadi sebuah sosok baru dalam penampilan fisiknya, kacau dalam penampilan internal dan eksternal. Hal itu tampak jelas dalam perilaku emosionalnya, yang menunjukkan ketidakseimbangan dan ketidaklogisannya. ${ }^{1}$ Masa remaja adalah masa dimana seseorang telah sampai pada masanya untuk berjuang menemukan jati diri yang sebenarnya, tanpa harus identik dengan orang lain. Karena, pada masa inilah seseorang akan mulai menunjukkan siapa dirinya kepada orang lain agar ia diakui atau sebagai penegasan identitas diri.

Pada masa perkembangan ini, bimbingan serta didikan dari orang sekitar sangatlah diperlukan agar remaja itu tidak salah dalam melangkah dan bergaul dengan dunia luar. Remaja juga harus dibina bagaimana cara bertindak dan mengambil keputusan juga diperhatikan agar bisa berpikir lebih dewasa. Terutama dalam hal akhlak (moral), karena akhlak adalah titik utama dalam hal bergaul dengan masyarakat luas. Musthafa al-'Adawy mengatakan, agar remaja dapat menghiasi dirinya dengan akhlak-akhlak mulia, mereka harus melihat perjalanan hidup Rasulullah saw dan mengikutinya. ${ }^{2}$ Karena dalam diri Rasulullah ada suri tauladan yang baik. Allah berfirman:

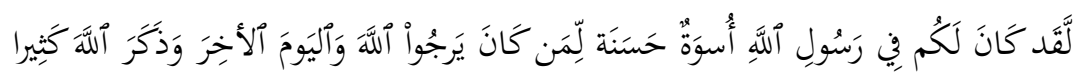

"Sesungguhnya telah ada pada (diri) Rasulullah itu suri teladan yang baik bagimu (yaitu) bagi orang yang mengharap (rahmat) Allah dan (kedatangan) hari kiamat dan dia banyak menyebut Allah." (Q.S. Al-Ahzab [33]: 21)

Dan rasul juga diutus untuk menyempurnakan akhlak, sebagaimana sabdanya:

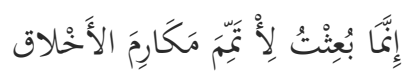

"Sesungguhnya aku diutus untuk menyempurnakan akhlak." (HR. Bukhari)

Pergaulan yang berarti hidup bermasyarakat perlu latihan sejak dini, bahkan sejak seseorang mengenal orang lain di luar dirinya sendiri. Sejak usia anak-anak hingga menjadi orang dewasa, bahkan orang tua sekalipun dalam kehidupannya tidak lepas dari apa yang disebut dengan pergaulan. Agar dapat diterima dengan baik di masyarakat, setidaknya seseorang harus bisa bersikap ramah. Yang disebut sikap ramah adalah sikap bersahabat dengan orang lain dan merasa senang saat berjumpa dengan mereka. ${ }^{3}$

${ }^{1}$ M. Sayyid Muhammad Az-Za'balawi, Pendidikan Remaja antara Islam \& Ilmu Jiwa (Jakarta: Gema Insani, 2007), 263.

${ }^{2}$ Mustafa al-'Adawy, Fikih Akhlak (Jakarta: Qisti Press, 2005), 4.

${ }^{3}$ Hafiz Hasan Mas'ud, 31 Etika Gaul Islami (Bandung: Mizan, 2005), 8. 
Ada lima faktor yang menyebabkan sikap ramah itu tumbuh dalam diri kita: Pertama, agama. Nilai kesempurnaan iman seseorang akan menumbuhkan kasih sayang dalam dirinya; Kedua, hubungan kekerabatan. Pada umumnya kita mencintai kerabat. Kita juga selalu menunjukkan kecintaan kepada mereka. Kita juga berupaya untuk dapat mencegah segala gangguan yang ditimbulkan dari mereka. Rasulullah saw pernah menyoroti hal ini dalam sabdanya: "Hubungan kekerabatan itu bila dekat (terjalin baik) akan membuat erat dan menimbulkan rasa saling menyayangi."; Ketiga, hubungan perkawinan. Seseorang yang mencintai istrinya akan mencintai setiap orang yang berhubungan kekerabatan dengan istrinya itu. Khalid bin Yazid

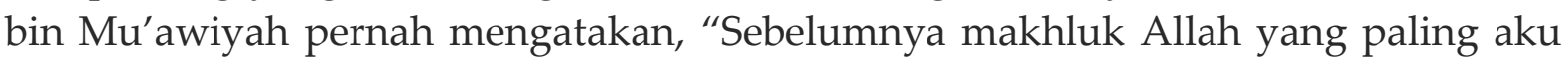
benci adalah keluarga Az-Zubair. Lalu pada saat aku menikahi salah seorang wanita dari kalangan mereka, mereka pun menjadi makhluk Allah yang paling aku cintai."; Keempat, sikap baik (al-birr), yaitu menunjukkan sikap yang baik kepada orang lain; Kelima, persaudaraan. Hal ini sebagaimana pernah dilakukan Rasulullah saw pada saat mempersaudarakan antara kaum Muhajirin dan Anshar, agar ikatan persaudaraan diantara mereka menjadi kuat dan sikap saling menyayangi itu terus tertanam dalam hati mereka. ${ }^{4}$ Dengan menjaga lima hal tersebut, maka akan menumbuhkan sikap ramah pada diri seseorang.

Ada 2 hal yang perlu diperhatikan dalam pergaulan, yaitu kemungkinan diterima secara baik atau ditolak oleh kelompok, lingkungan, bahkan di dalam masyarakat luas pada umumnya. Jika seseorang di dalam bergaul dapat diterima dengan baik di dalam komunitasnya, maka seseorang itu akan lebih percaya diri, timbul semangat untuk lebih berkarya dan berprestasi. Harga diri akan meningkat dengan sendirinya. Penghargaan demi penghargaan akan diperoleh dan kepercayaan akan terus meningkat yang datang dari komunitasnya. Meskipun demikian diperlukan pengendalian diri dengan selalu mendekatkan diri kepada Tuhan Yang Maha Esa seraya memohon petunjuk-Nya agar selalu diberikan bimbingan ke arah yang lebih baik.

Lingkungan masyarakat merupakan barometer/tolak ukur seseorang, apakah sikap, tutur kata dan perilaku seseorang dapat diterima oleh masyarakat luas atau tidak sesuai dengan norma dan tata nilai di dalam masyarakat itu sendiri. Norma adalah ukuran (benar salahnya, pantas atau tidaknya) perilaku seseorang dalam masyarakat. ${ }^{5}$

Keterampilan bergaul dapat dilihat sejak kanak-kanak hingga dewasa. Ketika masih kanak-kanak seseorang suka berkenalan dengan cara yang paling sederhana, yaitu tersenyum dan menyapa kawan-kawan yang baru dijumpainya. Ini merupakan awal terbentuknya rasa percaya diri dengan dunia pergaulan di lingkungannya yaitu dunia anak. Sampai saatnya seseorang memasuki dunia remaja dan dewasa, untuk belajar sesuai dengan usianya, karena pergaulan akan membawa kesuksesan di masa yang akan datang.

${ }^{4}$ Mas'ud, 8.

${ }^{5}$ Asmawati Burhan, Buku Ajar Etika Umum (Yogyakarta: Deepublish, 2019), 8. 
Zaman sekarang, pergaulan muda-mudi sangat memprihatinkan. Remaja sekarang lebih senang meniru budaya barat yang bertolak belakang dengan budaya timur. Hal ini disebabkan oleh para remaja yang bergaul dengan orang-orang yang kurang baik. Perkembangan informasi dan komunikasi saat ini juga merupakan sebab pergaulan remaja yang buruk. Terpaan media internet kepada remaja diyakini berpengaruh terhadap karakter mereka. Hal ini disebabkan media internet memiliki fungsi mempengaruhi, selain tiga fungsi yang lain yaitu fungsi informasi, pendidikan, dan hiburan. Fungsi mempengaruhi berarti media internet memiliki kekuatan informasi yang dapat mempengaruhi perilaku sosial manusia, sehingga media internet juga merupakan sarana yang efektif sebagai media pendidikan dan sosialisasi nilai-nilai yang positif dalam masyarakat. Namun demikian, pengaruh media internet juga dapat bersifat negatif, apabila media tersebut disalahgunakan. informasi dari media internet dapat mempengaruhi para penggunanya, baik sadar maupun tidak. ${ }^{6}$

Islam adalah agama yang baik dan adil, sesungguhnya Islam itu memberi perhatian terhadap remaja sekarang yang terus berubah. Remaja adalah penerus orang tua, agama, dan juga sebagai insan muslim yang berakhlak al-karimah (berakhlak mulia). Namun, remaja saat ini sudah tidak berpegang pada ajaran agama Islam terutama etika pergaulan yang semakin menyimpang. Simaklah sekitar kita, masih banyak remaja yang mengaku muslim tetapi sangat asing dengan Kitab Sucinya. Ada juga yang melantunkannya dengan suara merdu, tetapi akhlaknya tidak "semerdu" suaranya. ${ }^{7}$

Masalah etika, adalah masalah manusia pada umumnya di mana pun manusia berada dalam komunitasnya, pasti etika berperan sebagai pedoman tingkah laku baik-buruk dalam pergaulan sesama mereka. Etika tidak saja bertugas untuk menerapkan norma moral pada suatu situasi tertentu, melainkan juga untuk mendasari secara rasional norma yang berlaku. ${ }^{8}$ Remaja yang merupakan bagian dari manusia pada umumnya tentu juga memerlukan pedoman tingkah laku agar pergaulan sesama remaja dapat berjalan dengan baik sesuai dengan norma masyarakatnya atau sesuai dengan norma agama yang dianutnya, sehingga mereka terhindar dari pergaulan yang menyimpang yang tidak sesuai dengan norma masyarakat dan norma agama.

Berbicara tentang remaja atau masa muda berarti membicarakan tentang diri sendiri, hal ini sering didapati dalam banyak artikel (tulisan), bahkan masyarakat, orang tua, guru sering menyaksikan peran dan partisipasi remaja dan pemuda yang besar dalam membangun, menyumbang, dan mendukung perkembangan bangsa. Sebagaimana yang telah diketahui bahwa agama Islam menganjurkan agar anak didik menjadi seorang remaja muslim yang beretika, berakhlak al-karimah, dan

${ }^{6}$ Masykur Ihsan, "Pengaruh Terpaan Media Internet dan Pola Pergaulan Terhadap Karakter Peserta Didik" 10 (2016): 103.

7 Toto Tasmara, Menuju muslim kaffah: menggali potensi diri (Jakarta: Gema Insani, 2000), 29.

${ }^{8}$ Kees Bertens, Keprihatinan Moral, Telaah atas Masalah Etika (Yogyakarta: Kanisius, 2003), 9. 
dapat menjadi seorang pemimpin yang fleksibel (tidak kaku/bisa menyesuaikan) bagi masyarakat di masa yang akan datang karena setiap orang pasti akan menjadi seorang pemimpin. Sodiq mengatakan, bahwa menjadi pemimpin dalam kehidupan adalah impian setiap orang. ${ }^{9}$ Saat ini kesan yang ada dalam benak masyarakat tentang perilaku remaja justru cenderung kebanyakan negatif. Dimulai dari perkelahian antar pelajar, pornografi, kebut-kebutan, tindakan kriminal seperti pencurian, dan perampasan barang orang lain, pengedaran obat-obat terlarang dan bahkan yang lebih heboh adalah dampak pergaulan bebas yang semakin mengkhawatirkan. Pergaulan bebas yang terjadi hari ini dikalangan remaja sudah sangat mengkhawatirkan. Pasalnya pergaulan bebas atau biasa dikenal dengan istilah pacaran sudah menjadi hal yang wajar dilakukan remaja, bahkan ada anggapan tidak punya pacar itu rugi, malu tidak punya pacar, tidak punya pacar berarti tidak laku dan ungkapan semisal lainnya. ${ }^{10} \mathrm{Hal}$ itu menunjukkan pergaulan remaja yang mengkhawatirkan sekaligus memprihatinkan.

Dengan demikian, manusia akan mudah terjerumus ke berbagai penyelewengan dan kerusakan akhlak dengan melakukan perampasan hak orang lain, pelecehan seksual, pembunuhan, dan timbullah persaingan tidak sehat demi untuk mendapatkan apa yang diinginkan. Kemerosotan moral remaja saat ini banyak dipengaruhi oleh terpaan media informasi di abad millennium semakin merambah dengan cepat. Di daerah terpencil sekalipun terdapat tempat penyewaan VCD dan pemutaran film-film porno, belum lagi media cetak yang demikian bebas mengumbar informasi seksual yang semakin mempengaruhi remaja untuk melakukan hal-hal yang bertentangan dengan ajaran agama. Salah satu masalah yang perlu mendapat perhatian serius adalah bebasnya hubungan antar jenis di antara remaja (pemuda) yang menjadi tonggak pembaharuan. Pergaulan remaja diidentikkan dengan sekumpulan anak yang membentuk suatu kelompok (geng) dengan peraturan-peraturan tertentu yang beragam, dan tidak sedikit dari remaja yang salah dalam memilih pergaulan. Akibat dari salah memilih pergaulan diantaranya perlakuan yang semakin brutal, menggunakan barang-barang terlarang, semakin jauh dari orang tua, sering membolos saat sekolah dan sebagainya. Islam telah mengatur etika pergaulan remaja. Perilaku tersebut merupakan batasanbatasan yang dilandasi nilai-nilai agama. Oleh karena itu perilaku atau etika pergaulan tersebut harus diperhatikan, dipelihara, dan dilaksanakan oleh para remaja.

\section{B. METODE}

Objek penelitian ini adalah etika pergaulan yang terkandung dalam kisah nabi Yusuf yang terkandung dalam surat Yusuf ayat 23-34. Tulisan ini menggunakan metode tahlili, yaitu suatu metode tafsir yang digunakan dalam

${ }^{9}$ M. Shodiq Mustika dan Rusdin S. Rauf, The Ultimate Power of Shalat Tahajud (Jakarta: Qultum Media, 2012), 193.

${ }^{10}$ Muhammad Z. A, Ku Pilih Taat (Guepedia, 2019), 10. 
menjelaskan kandungan ayat al-Qur'an dari berbagai aspek dengan memperhatikan urutan-urutan makna yang terkandung dalam ayat al-Qur'an dengan mengikuti susunan surat-surat dan ayat-ayat sebagaimana yang tercantum dalam mushaf dengan sedikit-banyak melakukan analisis di dalamnya. Apapun yang dianggap perlu oleh seorang mufasir tahlili diuraikan dari kosakata, asbabun Nuzul, munasabah, dan lain-lain yang berkaitan degan teks atau kandungan ayat. ${ }^{11}$

Penelitian ini terfokus pada etika pergaulan yang terdapat pada kisah Nabi Yusuf as. dalam Al-Qur'an surat Yusuf ayat 23-34. Jadi dalam penelitian ini penyusun bermaksud mencari etika pergaulan yang terdapat dalam ayat tersebut, dengan mencari data-data dan sumber-sumber yang membahas mengenai ayat 23-34 surat Yusuf.

\section{HASIL DAN PEMBAHASAN}

1. Asbabun Nuzul Surat Yusuf

Surat yusuf yang ayatnya terdiri dari 111 ayat, adalah surat yang ke dua belas dalam perurutan Mushaf, sesudah surat Hud dan sebelum surat al-Hijr. Penempatannya sesudah surat Hud sejalan dengan masa turunnya, karena surat ini dinilai oleh banyak ulama turun setelah turunnya surat Hud. Surat Yusuf adalah satu-satunya nama dari surat ini. Ia dikenal sejak masa Nabi Muhammad saw. Penamaan itu sejalan juga dengan kandungannya yang menguraikan kisah Nabi Yusuf as. Berbeda dengan banyak nabi yang lain, kisah beliau hanya disebut dalam surat ini. Nama beliau disebut dalam surat al-An'am dan surat al-Mu'min (Gafir). ${ }^{12}$

Persoalan pokok yang dibicarakan dalam Surat ini seluruhnya mengenai kisah Nabi Yusuf as. (secara ringkas). Kisah ini disebut yang terindah karena beberapa alasan: Pertama, kisah ini paling terinci dari semua kisah yang ada dalam Qur'an; kedua, sepenuhnya mengenai perubahan-perubahan pada manusia; ketiga, penggambaran dengan warna yang hidup, dengan segala keterlibatan mereka secara rohani, serta indahnya ketakwaan dan kebenaran. ${ }^{13}$ Yusuf adalah putra Ya'qub Ibn Ishaq Ibn Ibrahim as. Ibunya adalah Rahil, salah seorang dari tiga istri Nabi Ya'qub as. Ibunya meninggal ketika adiknya, Benyamin, dilahirkan, sehingga ayahnya mencurahkan kasih sayang yang besar kepada keduanya melebihi kasih sayang kepada kakak-kakaknya. Ini menimbulkan kecemburuan yang akhirnya mengantar mereka menjerumuskannya ke dalam sumur. Ia dipungut oleh kafilah orang-orang Arab yang sedang menuju ke Mesir.

Ketika itu, yang berkuasa di Mesir adalah dinasti yang digelari oleh orang Mesir dengan Heksos, yakni "para pengembala babi". Pada masa kekuasaan Abibi yang digelari oleh al-Qur'an dengan al-Malik (bukan Fir'aun) Yusuf tiba dan dijual oleh kafilah yang menemukannya kepada seorang penduduk Mesir yang menurut

${ }^{11}$ La Ode Ismail Ahmad, "Konsep Metode Tahlili dalam Penafsiran Al-Qur'an," Shaut al Arabiyyah 4, no. 2 (2016): 53-66, https://doi.org/10.24252/saa.v4i2.1224. Diakses tanggal 3/9/2019.

12 M. Quraish Shihab, Tafsir Al-Misbah (Jakarta: Lentera Hati, 2002). 387

${ }^{13}$ Abdullah Yusuf Ali, Qur'an Terjemahan Dan Tafsirnya (Jakarta: Pustaka Firdaus, 1993), 548. 
Perjanjian Lama bernama Potifar yang merupakan kepala pengawal raja. Ini terjadi sekitar 1720 SM. Setelah perjalanan hidup yang berliku-liku, pada akhirnya Nabi Yusuf as. mendapat kedudukan tinggi, bahkan menjadi penguasa Mesir setelah menikah dengan putri salah seorang pemuka agama. Nabi Yusuf as. meninggal di Mesir sekitar1635 SM. Konon jasadnya diawetkan sebagaimana kebiasaan orangorang Mesir pada masa itu. Dan ketika orang-orang Israil meninggalkan Mesir, mereka membawa jasad/mumi beliau dan dimakamkan di satu tempat yang bernama Syakim. Demikian antara lain keterangan Thahir Ibn 'Asyur. ${ }^{14}$

Surat Yusuf turun di Mekah sebelum Nabi saw. berhijrah ke Madinah. Situasi dakwah ketika itu serupa dengan situasi turunnya surat Yunus, yakni sangat kritis, khususnya setelah peristiwa Isra dan Mi'raj dimana sekian banyak yang meragukan pengalaman Nabi saw. itu; bahkan sebagian yang lemah imannya menjadi murtad. Di sisi lain, jiwa Nabi Muhammad saw. sedang diliputi oleh kesedihan, karena istri beliau, Sayyidah Khadijah ra., dan paman beliau, Abu Thalib, baru saja wafat dan antara Baiat Aqabah pertama yang dilanjutkan Baiat Aqabah kedua. ${ }^{15}$ Dalam situasi semacam itulah turun surat ini untuk menguatkan hati Nabi saw.

Dalam kisah ini, pribadi tokohnya (Nabi Yusuf as.) dipaparkan secara sempurna dan dalam berbagai bidang kehidupannya. Dipaparkan juga aneka ujian dan cobaan yang menimpanya serta sikap beliau ketika itu. Perhatikanlah bagaimana surat ini dalam salah satu episodenya menggambarkan bagaimana cobaan yang menimpa beliau bermula dari gangguan saudara-saudaranya, pelemparan masuk ke sumur tua, selanjutnya bagaimana beliau terdampar ke negeri yang jauh, lalu rayuan seorang wanita cantik, kaya dan istri penguasa yang dihadapi oleh seorang pemuda normal yang pasti memiliki juga perasaan dan birahi; dan bagaimana kisahnya berakhir dengan sukses setelah berhasil istiqamah dan bersabar. Sabar dan istiqamah itulah yang merupakan kunci keberhasilan, dan itu pula yang dipesankan kepada Nabi Muhammad saw. pada akhir surat Hud. Di akhir surat Hud (ayat 115) disebutkan bahwa Allah swt. tidak menyia-nyiakan ganjaran al-muhsinin. Untuk membuktikan hal tersebut, dikemukakan kisah nabi Ya'qub as. dan Nabi Yusuf as., dua orang yang sabar sekaligus termasuk kelompok muhsinin yang tidak disia-siakan Allah swt. amal-amal baik mereka.

Diistimewakanlah Surat yang satu ini mengisahkan suka-duka Yusuf as., mengandung hikmah yang terbesar bagi seluruh manusia Mu'min untuk dibandingkan dengan kehidupan sendiri, bahwasanya bukanlah mudah hidup itu, yang kadang-kadang harus berkuah air mata, tetapi pula harus tabah menghadapi kesulitan, karena turun dan naik nasib adalah silih berganti, keadaan tidak tetap demikian saja. ${ }^{16}$

\section{Tafsir Al-Qur'an Surat Yusuf Ayat 23-24}

${ }^{14}$ Thahir Ibnu 'Asyur, Tafsir At-Tahrir Wa At-Tanwir, PDF, 197.

${ }^{15}$ Sayyid Quthb, Tafsir Fi Zhilalil Qur'an (Jakarta: Gema Insani, 2003), 301.

${ }^{16}$ Hamka, Tafsir Al-Azhar (Jakarta: Pustaka Panjimas, 1983), 160. 


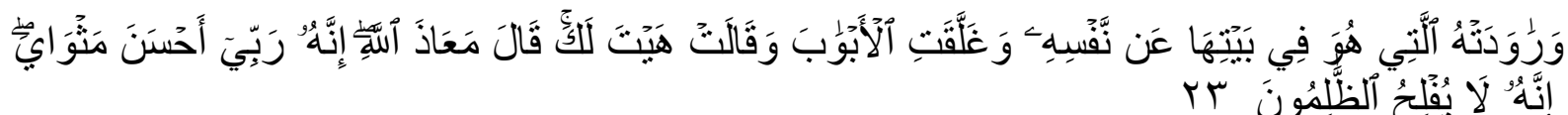

"Dan wanita (Zulaikha) yang Yusuf tinggal di rumahnya menggoda Yusuf untuk menundukkan dirinya (kepadanya) dan dia menutup pintu-pintu, seraya berkata: "Marilah ke sini". Yusuf berkata: "Aku berlindung kepada Allah, sungguh tuanku telah memperlakukan aku dengan baik". Sesungguhnya orang-orang yang zalim tiada akan beruntung."

Pada ayat-ayat yang lalu Allah menerangkan bahwa Perdana Menteri Mesir (Al-Aziz) yang membeli Yusuf memerintahkan kepada istrinya agar dia diberi tempat yang baik di istananya dan diperlakukan sebagai salah seorang keluarga istana karena dia mempunyai firasat bahwa Yusuf akan menjadi orang besar nantinya. ${ }^{17}$ Kata dan pada awal ayat diatas berfungsi sebagai perpindahan antara episode sebelumnya ke episode ini. ${ }^{18}$

Sekian lama sudah Yusuf as. berada di kediaman orang Mesir itu. Dari hari ke hari semakin jelas kehalusan budinya dan keluhuran akhlaknya. Kegagahan dan ketampanan wajahnya pun semakin menonjol. Kalau kita sepakat dengan Tabataba'i yang menjadikan ayat sebelumnya sebagai awal episode, maka itu berarti kini Yusuf as. talah mencapai kematangan usianya. Ia ketika itu belum mencapai tiga puluhan. Apapun yang terjadi, dan berapa pun usianya, yang jelas istri orang mesir itu (yang konon bernama Zalikha, atau zulaikha, atau Ra'il) melihat dan memperhatikan dari hari ke hari pertumbuhan jasmani dan perkembangan jiwa Yusuf. Tidak mustahil dia mengamati keindahan parasnya, kejernihan matanya, serta kehalusan budinya. Tidak mustahil dia tidak bosan duduk bersamanya menanyakan ihwal hidupnya.

Dari hari ke hari perhatian itu semakin bertambah, sejalan dengan pertumbuhan Yusuf as. dan suatu ketika, entah bagaimana sang istri sadar bahwa dia telah jatuh cinta kepada Yusuf. Hatinya bergejolak bila memandangnya, dan pikirannya kacau bila tidak melihatnya. Jika pada mulanya dia masih dapat memendam perasaannya, tetapi lama kelamaan desakan asmara tidak lagi dapat terbendung. Kalau pada mulanya, dia memandangnya sebagai seorang remaja kini pandangan itu telah berubah sehingga ketika dia, misalnya, memintanya membawakan segelas air, dia akan berkata, "mendekatlah! Mengapa menjauh? Duduklah di samping ku!" demikian seterusnya. Apalagi kalau benar riwayat Ibn Ishaq yang menyatakan bahwa suaminya bukanlah lelaki yang sempurna. Dia tidak dapat memberi kepuasan batin kepada istrinya. Apakah demikian atau tidak, yang pasti bara asmara dari saat ke saat membakar, dan dorongan nafsu

17 Departemen Agama RI, Al-Qur'an Dan Tafsirnya (Jakarta: Pelita, 1990), 636.

18 Shihab, Tafsir Al-Misbah, 6:423. 
dari waktu ke waktu memuncak. Dari hari ke hari pula wanita bersuami itu semakin berani. Jika pada mulanya isyarat-isyarat halus yang dinampakkannya, kini gerak dan geriknya semakin jelas dan tegas. Ini semakin menjadi-jadi karena Yusuf, pemuda tampan itu, berpura-pura tidak mengerti atau mengalihkan pandangan dan pembicaraan. ${ }^{19}$

Keadaan Yusuf memang jauh berbeda bahkan bertolak belakang dengan wanita itu. Sejak kecil, hatinya telah berkaitan dengan Allah swt. Pengalamannya menghadapi cobaan cukup banyak. Dan setiap cobaan berhasil dilaluinya dengan selamat, keselamatan yang diyakininya sebagai anugerah Allah swt. Kehadiran Allah swt. dalam jiwanya memang telah tertanam sejak mimpi dan penjelasan ayahnya. Kini dia menjadi seorang yang tidak banyak berbicara, walau hatinya selalu berdialog dengan Tuhan yang cinta-Nya memenuhi hatinya, dan yang anugerah-Nya selalu terasa olehnya.

Suatu ketika, setelah berkali-kali mencari perhatian dan merayu, wanita yang merupakan istri orang Mesir itu yang dia, yakni Yusuf tinggal di rumahnya dan yang biasanya harus ditaati, paling tidak karena jasa suaminya mengizinkan dia tinggal di rumahnya, (wanita itu) menggodanya berkali-kali dengan menggunakan segala cara untuk menundukkan dirinya, yakni diri Yusuf kepadanya, sehingga bersedia tidur bersamanya. Bila seorang perempuan telah merayau, sedang orang lain tidak ada dalam rumah, dapatlah kita mengerti bagaimana cara rayuan itu. ${ }^{20}$ Dan untuk tujuan itu, dia mempersiapkan diri dengan dandanan sebaik mungkin, lalu dia menutup rapat pintu-pintu yang dapat digunakan menuju tempat yang dia rencanakan berduaan dengan Yusuf. Dia menutupnya dengan sangat rapat sehingga sangat sulit dibuka. Tabir-tabir jendela pun pasti ditarik agar tidak ada celah untuk siapa pun melihat. Setelah itu dia menemui Yusuf seraya berkata dengan penuh harap dan rayu, "Marilah ke sini, laksanakan apa yang kuperintahkan," atau "Inilah aku siap untuk memenuhi keinginan-mu."

Sungguh Yusuf tidak menduga situasi akan menjadi demikian. Kekasihnya (yakni Allah swt.) yang tidak pernah luput dari ingatannya, kini tampil begitu jelas, anugerah-Nya yang sedemikian banyak pun muncul seketika di dalam benaknya. Boleh jadi nampak juga di pelupuk matanya kebaikan dan jasa tuan rumah, suami wanita yang mengajaknya itu. Dan seketika itu Yusuf berkata singkat, "Aku berlindung kepada Allah". Aku melindungkan diriku kepada Allah dari melakukan perbuatan itu. ${ }^{21}$ "Perlindungan Allah" (maksudnya: Aku memohon perlindungan Allah yang maha kuasa dari godaan dan rayuanmu). Sungguh Dia adalah Tuhanku yang menciptakan aku, Dia yang membimbing dan berbuat baik kepadaku dalam segala hal. Dia telah memperlakukan aku dengan baik sejak kecil, ketika aku dibuang ke dalam sumur, kemudian menganugerahkan

${ }^{19}$ Shihab, 6:424.

${ }^{20}$ Hamka, Tafsir Al-Azhar, 208.

${ }^{21}$ Qutb, Tafsir Fi Zilalil Qur'an, 340. 
kepadaku tempat yang sangat agung di hati suamimu, sehingga dia menguasakan kepadaku apa yang dia miliki dan mengamanahkannya untuk aku pelihara. Bila aku melanggar perintah Tuhanku dengan mengkhianati orang yang mempercayaiku, maka pastilah aku berlaku zalim. Sesungguhnya orang-orang yang zalim itu tiada akan beruntung memperoleh apa yang diharapkannya."

Permintaan Yusuf dalam menolak cinta Zulaikha ada tiga: Pertama, aku berutang budi kepada Tuhanku, begitu juga kau, terhadap suamimu, Aziz; Kedua, budi baik, sopan santun dan kehormatan yang telah diberikannya kepadaku, berhak dia menerima lebih dari sekadar terima kasih dari pihakku; Ketiga, bagaimanapun juga, tidakkah kau lihat bahwa kau sedang menyimpan cinta dosa, dan bahwa segala yang dihasilkan dari perbuatan dosa tak ada yang baik? Kita semua harus mematuhi hukum, - manusia dan agama. ${ }^{22}$

Demikian Yusuf menyebutkan tiga hal setelah tiga hal pula dilakukan oleh wanita itu: merayu, menutup rapat-rapat pintu, dan mengajak berbuat. Dijawabnya dengan memohon perlindungan Allah, mengingat anugerah Allah swt. antara lain melalui jasa-jasa suami wanita itu serta menggarisbawahi bahwa ajakan itu adalah kezaliman, sedang orang-orang zalim tidak pernah akan beruntung. ${ }^{23}$

Kata (راودته) rawadathu terambil dari kata (راود) ra>wada yang asalnya adalah (راد) rada. Ia adalah upaya meminta sesuatu dengan lemah lembut agar apa yang diharapkan (enggan diberi oleh yang dimintai) dapat diperoleh. Bentuk kata yang digunakan ayat ini mengandung makna upaya berulang-ulang. Pengulangan itu terjadi karena langkah pertama ditolak, sehingga diulangi lagi, demikian seterusnya.

Kata ini, menurut al-Biqa'i, dalam berbagai bentuk yang menghimpun ketiga hurufnya, mengandung makna bulat atau berputar. Dari makna ini lahir makna seperti menuju satu tempat dengan sengaja, kembali, lemah lembut, kesempatan, melakukan tipu daya, pengamatan yang baik, juga dalam arti bingung, dan pusing, mengharapkan perolehan sesuatu, dan masih banyak lagi makna-makna lainnya. Jika kata itu menunjuk kepada sesuatu, maka ia antara lain bermakna mawar, karena kembang ini harum dicium dan bundar, pemberani karena ia mondar-mandir berputar dengan gagah untuk menguasai dan mengalahkan lawannya. Ia juga berarti lingkaran, yakni sesuatu yang bulat. Walhasil kata ini memiliki banyak makna dan tidak keliru jika sebagian dari makna-makna itu mengisyaratkan apa yang dilakukan oleh wanita bersuami itu dengan penuh harap untuk mendapatkan perolehannya, baik dengan lemah lembut, maupun dengan melakukan tipu daya, menampakkan diri sebagai mawar walau untuk itu dia bingung dan pusing karena apa yang diinginkan dan telah diusahakannya dengan gagah berani belum juga tercapai.

22 Ali, Qur'an Terjemahan Dan Tafsirnya, 558.

${ }^{23}$ Shihab, Tafsir Al-Misbah, 6:424. 
Kata (غلقت) gallaqat terambil dari kata (غلق) galaqa yang berarti menutup. Patron kata yang digunakan ayat ini mengandung makna menutup dengan berulang-ulang sehingga sulit untuk dibuka. Merapatkan pintu, menguncinya, menutup celahnya dan mengecek kembali apakah benar-benar telah terkunci atau belum. Itu antara lain yang dilakukan oleh pelaku kata tersebut.

Kata (هيت) haita dari segi bahasa, juga mempunyai banyak arti. Cara membacanya pun berbeda-beda. Di samping yang disebut di atas, ada juga yang membacanya hiyat atau hitu dan haitu. Maknanya pun dapat berbeda-beda. Dari rangkaian huruf-hurufnya lahir beberapa makna, yang kesemuanya merujuk ke makna kehendak agar mengikuti perintah. Ia dapat berarti berteriak memanggil. Dari akar kata yang sama lahir kata (الهيت) al-hait yaitu tanah yang belum diketahui, seakan-akan mengundang orang untuk mengenalnya. Juga kata (تيه) tih yaitu keangkuhan yang menjadikan pelakunya menuntut agar dipenuhi kehendaknya. Demikian antara lain makna kata-kata tersebut menurut al-Biqa'i. Semua makna itu dapat dicakup oleh kata singkat yang diucapkan oleh wanita bersuami yang merayu Yusuf itu.

Kata (لك) laka yang disebut setelah kata haita bertujuan menegaskan bahwa perintah itu atau ajakan dan kesiapan khusus itu diperuntukkan semata-mata untuk mitra bicara dalam hal ini adalah Yusuf as. ${ }^{24}$ Sedikit aneh pandangan Tahir Ibn 'Asyur yang menduga bahwa permintaan semacam ini dari seorang wanita pada masa itu adalah sesuatu yang tidak aneh terjadi di istana dan rumah-rumah mewah. Maksudnya pada masa itu seorang wanita boleh saja menikmati hamba sahayanya yang lelaki sebagaimana seorang lelaki dibolehkan menikmati hamba sahayanya yang wanita.

Sekali lagi pandangan atau dugaannya itu aneh, karena seperti akan terbaca pada ayat 29 berikut apa yang dilakukan oleh wanita itu dikecam oleh suaminya dan dinilainya dosa. Wanita-wanita semasa dan sekota pun yang mendengar kejadian itu menilainya sangat buruk dan memandang pelakunya dalam kesesatan yang sangat jelas (ayat 30). Di sisi lain, sifat wanita yang monogam menjadikan wanita normal apalagi yang beradab sendiri, memandang buruk hal tersebut. Berbeda dengan lelaki yang memang pada umumnya bersifat poligam. Hal ini pun dapat terlihat pada jantan binatang yang dengan kekuatannya melawan siapa yang mendekati betinanya.

Tabataba'i, mengomentari kata (لهاذل) ma'azlallah dengan berkata bahwa ajakan wanita itu dihadapi oleh Yusuf as. bukan dengan mengancam, tidak juga dengan berkata: "Aku takut kepada suamimu" atau "Aku tak ingin mengkhianatinya" atau "Aku keturunan para Nabi, dan orang baik-baik" atau "Kesucian dan kehormatanku menghalangi aku memenuhi ajakanmu." Tidak juga berkata: "Aku mengharap ganjaran Allah swt. atau takut siksa-Nya" dan lain-lain sebagainya. Seandainya hatinya bergantung kepada sesuatu yang 
merupakan sebab-sebab lahiriah, tentulah itu yang pertama terucapkan olehnya saat dia didadak seperti itu. Karena demikianlah tabi'at manusia pada umumnya. Yusuf as. tidak demikian, karena tidak ada sesuatu di dalam hatinya kecuali Tuhannya. Matanya tidak tertuju kepada selain-Nya. Itulah tauhid yang murni yang dihasilkan oleh cinta Ilahi sehingga menjadikan dia lupa segala sesuatu bahkan melupakan dirinya sendiri, sampai dia tidak berkata: Aku berlindung kepada Allah dari rayuanmu atau makna semacamnya. Tetapi dia hanya berkata: "Ma'azlallah / perlindungan Allah." Alangkah jauh perbedaan antara ucapannya ini dengan ucapan Maryam as. ketika malaikat tampil kepadanya dalam bentuk manusia. Ketika itu Maryam berkata:

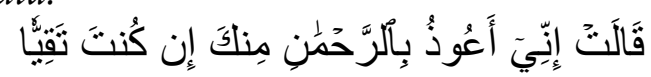

"Sesungguhnya aku berlindung dari padamu kepada Tuhan Yang Maha pemurah, jika kamu seorang yang bertakwa". (QS. Maryam [19]: 18).

Kata (ري) Rabbi yang diterjemahkan di atas dengan Tuhanku ada juga yang memahaminya dalam arti tuanku. Dengan demikian, Yusuf as. berkata perlindungan Allah, sesungguhnya dia, yakni suamimu yang juga tuanku telah memperlakukan aku dengan baik. ${ }^{25}$

Dalam buku wawasan al-Qur'an, Quraish Shihab memilih pendapat tersebut. Tetapi setelah merenung lebih lama dan membaca alasan-alasan para pakar, beliau berkesimpulan bahwa memahami kata (ربي) Rabbi dalam arti tuanku bukanlah pendapat yang kuat. Seandainya suami wanita yang dimaksudnya, tentulah lebih tepat Yusuf berkata: "Sesungguhnya tidak beruntung orang-orang yang khianat" bukan orang-orang yang zalim, sebagai mana ucapan Yusuf as. sendiri ketika berada dalam penjara: (Yusuf berkata), "Yang demikian itu agar dia (suami wanita itu) mengetahui bahwa sesungguhnya aku tidak berkhianat kepadanya di belakangnya, dan bahwa Allah tidak meridai tipu daya orang-orang yang berkhianat" (ayat 52). Di sisi lain, Yusuf tidak pernah menganggap orang Mesir suami wanita itu adalah tuannya karena dia yakin benar bahwa dia adalah manusia merdeka bukan hamba sahaya. Bahkan terhadap raja masanya Yusuf as. tidak menjulukinya dengan Rabb / pemelihara kecuali pada saat menunjuk hubungan seorang hamba sahaya dengannya (ayat 42-51), dan ketika berbicara tentang dirinya dia menggunakan kata $R a b b$, tetapi kata itu digunakannya menunjuk kepada Allah swt. Raja berkata, "Bawalah dia kepadaku." Maka tatkala utusan itu datang kepadanya (Yusuf), dia (Yusuf) berkata, "kembalilah kepada Rabbika / tuanmu dan tanyakanlah kepadanya bagaimana halnya wanita-wanita yang telah memotong tangannya. Sesungguhnya Rabbi / Tuhanku Maha Mengetahui tipu daya mereka" (ayat $50)$.

2. Q.S. Yusuf Ayat 24

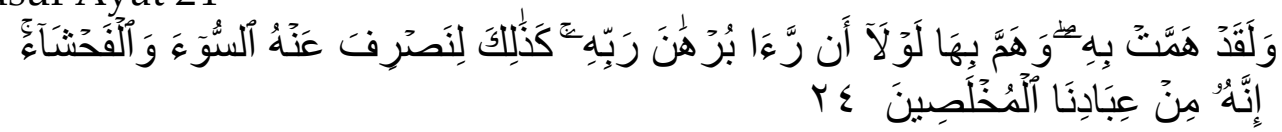

25 Shihab, 6:428. 
"Sesungguhnya wanita itu telah bermaksud (melakukan perbuatan itu) dengan Yusuf, dan Yusuf pun bermaksud (melakukan pula) dengan wanita itu andai kata dia tidak melihat tanda (dari) Tuhannya. Demikianlah, agar Kami memalingkan dari padanya kemungkaran dan kekejian. Sesungguhnya Yusuf itu termasuk hambahamba Kami yang terpilih."

Banyak sekali faktor lahiriah yang seharusnya mengantar Yusuf as. menerima ajakan wanita itu. Dia seorang pemuda yang belum nikah; yang mengajaknya adalah seorang wanita cantik lagi berkuasa. Kebaikan wanita itu terhadap Yusuf as. pasti banyak, dan perintahnya sebelum peristiwa ini dan juga sesudahnya selalu diikuti Yusuf. Wanita itu pasti sudah berhias dan memakai wewangian, suasana istana pasti nyaman. Pintu-pintu pun telah ditutup rapat. Gorden dan tabir pun telah ditarik. Rayuan dilakukan berkali-kali bahkan dengan tipu daya sampai dengan memaksa, yang mengakibatkan bajunya sobek. Boleh jadi Yusuf as.

Sebagai seorang yang mengetahui seluk beluk rumah dan kepribadian wanita itu tahu bahwa kalaupun ternyata ketahuan oleh suaminya, maka sang istri yang lihai itu akan dapat mengelak. Apalagi suaminya amat cinta padanya. Namun sekali lagi semua faktor pendukung terjadinya kedurhakaan tidak mengantar Yusuf tunduk di bawah nafsu dan rayuan setan. ${ }^{26}$

Di sini boleh jadi timbul dugaan. Jangan sampai penolakan Yusuf as. itu disebabkan karena tidak ada birahi pada dirinya. Jangan sampai dia bukan lelaki sejati, atau jangan sampai karena dia didadak sedemikian rupa, atau karena yang mengajaknya adalah wanita yang dihormati atau ditakutinya sehingga "kekuatannya" menghilang sementara sebagaimana dapat terjadi pada pengantin baru. Maka dari itu, untuk menampik hal tersebut, Allah swt. dalam ayat ini menegaskan bahwa sungguh Aku bersumpah, wanita itu telah bermaksud dengan penuh tekad melakukan kedurhakaan dengannya, karena tiada akal, tiada pula moral atau agama yang membendungnya, hasratnya pun meluapluap, dan Yusuf as. pun, anak muda yang tampan lagi sehat bugar itu telah bermaksud juga melakukan sesuatu juga dengannya andaikata dia tidak melihat bukti dari Tuhannya, yaitu hikmah dan ilmu yang dianugerahkan kepadanya. Bukti yang bersumber dari Tuhannya itulah yang menghalangi dia melakukan kehendak hatinya itu. Demikianlah, yakni seperti itulah kami lakukan agar Kami memalingkan darinya kemungkaran zina dan kekejian yakni kedurhakaan. Sesungguhnya dia, yakni Yusuf as. termasuk hamba-hamba kami yang terpilih sehingga setan tidak berhasil menundukkannya.

Banyak sekali komentar ulama dan riwayat tentang ayat ini (برهان ربه) burhana Rabbihi / bukti dari Tuhannya.

${ }^{26}$ Shihab, 6:429. 
Ada yang berpendapat seperti ditulis al-Qurtubi dan dikuatkan oleh Rasyid Rida bahwa tekad wanita yang disebut di sini bukan untuk melakukan perbuatan keji, tetapi untuk membalas dendam setelah menyadari keengganan Yusuf as. memenuhi keinginannya. Dia telah bermaksud memukul dan mencederai Yusuf as. yang telah menghinanya sebagai tuannya dan pemilik istana. Di sisi lain Yusuf as. pun bermaksud membela diri dan memukulnya. Pendapat ini boleh jadi lahir dari keengganan penganutnya untuk melukiskan suatu perbuatan yang dapat dinilai buruk kepada seorang nabi. Ini adalah sesuatu yang baik, tetapi sayang tidak ada indikator dalam redaksi atau konteks ayat ini yang mendukungnya. Di sisi lain kita dapat berkata bahwa peristiwa ini terjadi sebelum pengangkatan beliau sebagai nabi, bahkan walau sesudahnya. Bukankah para nabi manusia normal juga yang pasti memiliki birahi? Apalagi di sini dinyatakan bahwa hal tersebut tidak terjadi.

Selanjutnya ada juga yang berpendapat bahwa kehendak dan tekad bertingkat-tingkat. Tentu tekad wanita itu sudah sedemikian bulat. Sudah lama dia merencanakannya., bahkan sudah berkali-kali dia berusaha dengan berbagai cara yang halus. Tekadnya kali ini adalah untuk melakukan sesuatu. Adapun tingkat kehendak Yusuf as. maka itu baru pada tahap pertama, baru pada tahap terlintas dalam pikiran. Demikian diuraikan oleh Muhammad Sayyid Tantawi, Sayyid Qutub juga berpendapat serupa. Tulisannya, “Wanita itu berkehendak melakukan suatu perbuatan nyata, sedang Yusuf berkehendak dalam bentuk kehendak hati." 27

Ada juga yang berpendapat bahwa wanita itu telah bermaksud melakukan perbuatan keji, dan Yusuf pun bermaksud serupa. Seandainya dia tidak melihat bukti dari Tuhannya, niscaya dia melanjutkan tekadnya dan benar-benar melakukan perbuatan keji itu. Pendapat ini antara lain dikemukakan oleh pakar tafsir al-Qurtubi dan al-Zamakhsyari. Asy-Sya'rawi lain pula pendapatnya. Menurutnya, makna penggalan itu adalah; seandainya dia tidak melihat bukti dari Tuhannya, niscaya dia berkehendak juga. Ini berarti, dalam kenyataan, Yusuf as. tidak berkehendak. Redaksi itu sengaja disusun demikian untuk menunjukkan bahwa dia adalah lelaki yang normal dan dia memiliki kehendak. Thabathaba'i berpendapat hampir serupa. Hanya dia menggarisbawahi bahwa keterhindaran Yusuf as. dari cobaan yang begitu besar dan yang dapat menghancurkan gunung dan meluluhkan batu karang setegar apa pun adalah suatu peristiwa luar biasa yang lebih serupa dengan mimpi daripada kenyataan. Tidak ada yang dapat membendung hal tersebut dari diri Yusuf as., sehingga dia dapat mengatasi faktor-faktor godaan yang demikian besar, kecuali prinsip tauhid yang murni yaitu keimanan kepada Allah swt., atau katakanlah cinta Ilahi yang memenuhi seluruh totalitas wujudnya. Cinta Ilahi itu telah menjadi perhatian penuh hatinya sehingga tidak ada lagi tempat di dalam hatinya walau sebatas jari untuk selain Allah swt. Tabataba'i menulis bahwa penggalan ayat itu

27 Shihab, 6:430. 
bermakna: Demi Allah, wanita itu telah berkeinginan dan bertekad. Dan demi Allah juga, seandainya Yusuf tidak melihat bukti dari Tuhannya, maka dia pun pasti berkeinginan dan bertekad dan hampir terjerumus ke dalam maksiat.

Memang demikian itulah cinta kepada Allah swt. yang dilukiskan oleh kaum sufi. Ketika ditanya tentang siapa yang wajar disebut pencinta Allah, sufi besar al-Junaid menjawab, "Ia adalah yang tidak menoleh kepada dirinya lagi, selalu dalam hubungan intim dengan Tuhan melalui zikir, senantiasa menunaikan hakhak-Nya. Dia memandang kepada-Nya dengan mata hati, terbakar hatinya oleh sinar hakikat Ilahi, meneguk minum dari gelas cinta kasih-Nya, tabir pun terbuka baginya sehingga sang Maha Kuasa muncul dari tirai-tirai gaib-Nya, maka tatkala berucap, diam, ia selalu bersama Allah. Sungguh, semua yang dilakukan demi untuk bersama Allah."

Begitulah lebih kurang keadaan Yusuf as. yang dilukiskan oleh Tabataba'i, sehingga walau dia memiliki birahi sebagaimana manusia normal namun karena dia melihat Allah swt. dan bukti-bukti yang bersumber dari-Nya, maka jangankan tekad atau keinginan, perhatian dan pandangannya pun tidak lagi tertuju kepada wanita itu atau wanita lain. Di sinilah perbedaan pendapat Tabataba'i dengan pendapat sebelum ini yang mengesankan bahwa keinginan bercinta telah terjadi, walau bukan dalam tingkat serupa dengan wanita itu. Menurut Tantawi, atau kalau menurut az-Zamakhsyari, keinginan bercinta memang terjadi, tetapi kejerumusan tidak terjadi.

Kata (الفحشاء) alfahsya' adalah perbuatan yang sangat keji. Kata ini digunakan al-Qur'an dalam konteks hubungan dua lawan jenis yang tidak sah, dan dipahami dalam arti Zina. ${ }^{28}$

Firman-Nya: (إنه من عبادن المخلصين) Innahu> min 'iba>dina al-Mukhlashin/ Sesungguhnya dia termasuk hamba-hamba Kami yang terpilih merupakan pernyataan dari Allah swt. menyangkut Yusuf as., sekaligus bukti bahwa setan tidak akan berhasil mempengaruhinya, karena seperti diketahui, iblis sendiri mengakui bahwa, "Demi kekuasaan-Mu, aku pasti akan menyesatkan mereka semuanya, kecuali hamba-hamba Mu al-Mukhlashin/ yang terpilih" (Q.S. Sad [38]: 82-83). Di atas telah dinyatakan bahwa Yusuf as. adalah salah seorang dari hamba Allah yang terpilih.

\section{Etika Pergaulan yang Terkandung dalam Al-Qur'an Surat Yusuf ayat 23-24.}

\section{Menjaga Pandangan.}

Mata adalah sahabat sekaligus penuntun bagi hati. Mata mentransfer berita-berita yang dilihatnya ke hati sehingga membuat pikiran berkelana karenanya. Karena melihat secara bebas bisa menjadi faktor timbulnya keinginan dalam hati, maka syariat yang mulia ini telah memerintahkan kepada kita untuk menundukkan pandangan kita terhadap sesuatu yang dikhawatirkan menimbulkan akibat yang buruk. 
Salah satu upaya agar hati kita hidup adalah dengan menjaga pandangan. Menjaga pandangan besar pengaruhnya. Ketika sesorang tidak sungguhsungguh menjaga pandangan, dia akan merasakan pengaruh buruk ke ruhaninya. Salat tidak bisa khusyuk, munajat tidak nikmat, hati gersang, sering resah dan gelisah.

Nabi Muhammad saw. dan Nabi Yusuf as. adalah pribadi yang sangat menjaga pandangannya dari setiap sesuatu yang Allah haramkan melihatnya. Beliau menghormati kaum muslimah dengan menjaga pandangan dari melihat mereka secara tidak halal. Betapa pun, kecantikan dan keindahan ada yang lebih berhak untuk menikmatinya, yaitu melalui jalan pernikahan. Rasulullah tidak terbelenggu dengan kecintaan berlebihan pada keindahan dunia. Beliau menempatkan Allah sebagai cinta tertinggi dan di sanalah ada samudera kenikmatan ruhiyah yang tak bertepi. ${ }^{29}$

Laki-laki yang tidak bisa menahan pandangan, dia akan dibelenggu oleh gelora syahwat sebagai buah dari pandangannya yang tidak halal. Kita dengar sekarang, ada sebagian anak kecil yang sudah berani memperkosa teman wanitanya. Kita berlindung pada Allah dari kekejian seperti ini bagi kita dan anak keturunan kita. Mengapa bisa terjadi hal seperti ini? Ini muncul karena pandangan tidak terjaga. Anak kecil saja, ketika membiarkan matanya liar, dia bisa berbuat tidak senonoh. Terlebih jika kita bicara tentang kelakuan remaja atau orang-orang dewasa. Mereka bisa berbuat lebih buruk.

Menjaga pandangan, terutama bagi kaum laki-laki, memang sangat tidak mudah. Kita lihat saat ini tidak sedikit tayangan-tayangan atau sajian-sajian media masa yang mudah menggelorakan syahwat. Akibatnya, tidak sedikit lakilaki yang kemudian tergerak nafsunya. Dalam perkara menahan pandangan ini, Umar Ibn al-Khottob ra. Pernah berkata, "lebih baik aku berjalan di belakang seekor singa daripada berjalan di belakang wanita." Wanita bukanlah makhluk yang harus dijauhi, sebab bagaimana mungkin kaum laki-laki hidup tanpa lawan jenisnya. Namun atas mereka, perlu sikap hati-hati.

Nabi Yusuf as. ketika melihat Zulaikha yang rupawan, beliau gadal basar (menjaga pandangan). Dari pandangan itu, beliau tidak terlalu terpengaruh. Tapi ketika sebaliknya, Zulaikha melihat nabi Yusuf as., muncul keinginan syahwat nya yang meledak-ledak. Menjaga pandangan adalah sumber ketenangan batin. Pemuas batin kita adalah Allah dan Dia akan menilai sejauh mana ketaatan kita sehingga layak dianugerahi hati dan jiwa yang tenteram. ${ }^{30}$ Pandangan merupakan salah satu panah beracun iblis. Barang siapa melepaskan pandangan secara sembarangan, ia akan menyesal. Menjaga pandangan mendatangkan sejumlah manfaat: ${ }^{31}$ Pertama, melaksanakan perintah Allah yang merupakan

${ }^{29}$ Abdullah Gymnastiar, Meraih Bening Hati Dengan Manajemen Qolbu (Jakarta: Gema Insani Press, 2002), 43.

${ }^{30}$ Gymnastiar, 46.

${ }^{31}$ Ibn Qoyyim al-Jawziyyah, Kiat Membersihkan Hati Dari Kotoran Maksiat (Jakarta: PT. Serambi Ilmu Semesta, 2008), 228. 
tujuan kebahagiaan hamba di dunia dan akhirat.; Kedua, mencegah pengaruh panah beracun yang bisa membinasakan itu masuk ke kalbu; Ketiga, membuat kalbu senang bersama Allah. Sebaliknya melepaskan pandangan secara liar mencerai-beraikan kalbu sekaligus membuatnya jauh dari Allah; Keempat, membuat kalbu kuat dan bahagia; Kelima, menyelimuti kalbu dengan cahaya; Keenam, melahirkan firasat yang benar sebagai sarana untuk mengetahui yang benar dan yang batil serta yang jujur dan yang dusta; Ketujuh, melahirkan keteguhan, keberanian, dan kekuatan; Kedelapan, membendung jalan setan menuju kalbu. Masuknya setan melalui pandangan lebih cepat daripada masuknya udara ke dalam ruangan; Kesembilan, membersihkan pikiran, melepaskan pandangan akan membuat pikiran lupa dan terhijab dari Allah sehingga ia mengikuti hawa nafsu dan lalai dalam berzikir kepada-Nya;

Kesepuluh, antara mata dan kalbu terdapat lorong yang menghubungkan keduanya. Jika yang satu baik, yang lain ikut baik, dan jika yang satu rusak, yang lain ikut rusak. ${ }^{32}$

Maka dari itu, sudah seharusnya para remaja Muslim menjaga pandangan mereka sebagaimana yang telah dilakukan oleh Nabi Yusuf, sehingga mereka dapat terjaga dari perbuatan maksiat dan dosa serta dapat memiliki hati yang bersih yang diliputi dengan cahaya kebaikan.

\section{Menutup Aurat}

Menutup aurat merupakan bagian yang sangat penting bagi seorang muslim dan muslimah. Tubuh adalah bagian pribadi yang harus dijaga agar tidak terjadi pelecehan. Namun, sekarang banyak sekali perempuan yang memakai pakaian namun hakikatnya mereka telanjang karena menampakkan auratnya. Hal ini dikarenakan kebudayaan barat yang terus menerus menggerogoti keimanan muslim dan muslimah terutama generasi muda. Keminderan dan gemerlapnya "kemajuan" budaya barat yang tidak sesuai dengan Islam dan budaya ketimuran telah meracuni pola pikir kita. Betapa mudahnya kita menemukan perempuan-perempuan yang pada hakikatnya mereka tidak menggunakan pakaian.

Wanita-wanita yang digambarkan Rasul dalam hadis tersebut, sekarang banyak sekali kita lihat. Bahkan, itu sudah menjadi sesuatu yang mentradisi dan dianggap lumrah. Padahal, aurat perempuan yang tidak boleh dilihat oleh lakilaki yang bukan mahramnya adalah seluruh tubuh kecuali telapak tangan dan wajahnya.

Dengan menutup aurat wanita akan terjaga dari pandangan laki-laki yang tidak semestinya. Maka setiap muslim dan muslimah wajib menutup auratnya, bukan seperti yang dilakukan oleh Zulaikha yang menunjukkan auratnya ketika hendak menggoda Nabi Yusuf as.

32 al-Jawziyyah, Kiat Membersihkan Hati Dari Kotoran Maksiat, 232. 


\section{Menjauhi Perbuatan Zina}

Secara umum zina diartikan dengan melakukan hubungan badan atau seksual dengan lawan jenis yang bukan pasangan sah dari hasil pernikahan. Zina merupakan perbuatan dosa besar yang sangat tercela. Perbuatan zina sangat dikutuk oleh Allah. Selain menjauhkan seseorang dari Tuhan-nya, zina juga menyebabkan seseorang terhalang meraih kesuksesan. ${ }^{33}$ Dengan demikian berbuat zina berarti menutup rapat-rapat pintu sukses. Menjauhi zina ini merupakan salah satu etika pergaulan yang telah dicontohkan oleh Nabi Yusuf as. ketika beliau menolak ajakan Zulaikha untuk melakukan perbuatan yang nista itu, dan juga Nabi Yusuf memilih dipenjara daripada harus mengikuti ajakan wanita tersebut. Sehingga Nabi Yusuf menjadi orang yang sukses dikemudian hari setelah berhasil melalui berbagai macam ujian yang dihadapinya. Semoga para remaja dan generasi muda kita bisa mengikuti jejak langkah Nabi Yusuf as. dalam pergaulan dan menggapai kesuksesan di masa yang akan datang.

\section{Memiliki Sikap Rendah Hati}

Rendah hati dalam bahasa arab adalah tawadu yaitu orang yang menghargai orang lain, ia berkata dengan lemah lembut dan mudah memaafkan orang lain. Lawan dari rendah hati adalah tinggi hati atau sombong atau congkak. Rendah hati merupakan sifat terpuji. Rendah hati merupakan sikap atau perbuatan yang tidak menyombongkan diri. Rendah hati berbeda dengan rendah diri. Rendah diri berarti minder atau tidak memiliki rasa percaya diri karena merasa mempunyai kekurangan. Sikap rendah diri harus dihindari, sedangkan sikap rendah hati harus kita miliki. ${ }^{34}$ Adapun ciri-ciri dari orang yang memiliki sikap rendah hati ialah: 1) Tidak pernah memandang rendah orang lain; 2) Selalu menghormati orang lain dimanapun dan kapanpun dia berada; 3) Tidak pernah membeda-bedakan teman. Ia tidak memilih-milih teman antara yang kaya, pintar, ataupun yang kurang mampu; 4) Memandang bahwa orang lain sebagai ciptaan Tuhan memiliki keunikan dan keistimewaan, sehingga dia senantiasa membuat orang lain merasa penting; 5) Orang yang rendah hati akan membahagiakan hati sesama; 6) Mau mendengar pendapat, saran dan menerima kritik dari orang lain; 7) Senantiasa berani mengakui kesalahan dan meminta maaf jika melakukan kesalahan atau menyinggung perasaan orang lain; 8) Dia dapat menyesuaikan kondisi emosi dan egonya untuk menempati kondisi emosi dan ego teman bicaranya sehingga temannya merasa didengarkan dan dihargai; 9) Mengutamakan kepentingan yang lebih besar.

\section{KESIMPULAN}

33 Amirulloh Syarbini, Doa-Doa Khusus Wanita (Jakarta: PT. Elex Media Komputindo, 2011), $59-60$.

${ }^{34}$ Mohammad Fauzi, Akidah Akhlak (Sidoarjo: Media Ilmu, 2008), 23. 
Dari uraian sebelumnya dapat disimpulkan bahwa etika pergaulan remaja yang terdapat dalam kisah Nabi Yusuf; telaah tafsir tarbawi surat Yusuf ayat 23-24, yaitu: Pertama, menjaga pandangan

Dengan menjaga pandangannya, orang akan mampu mengendalikan syahwatnya dan terhindar dari perbuatan yang dilarang oleh agama. Dan semakin dekat dengan Allah karena hatinya menjadi bersih serta kalbunya akan menjadi kuat dan bercahaya; Kedua, menutup aurat. Ketika seseorang menutup auratnya, maka dia akan terjaga dari pandangan buruk orang-orang yang tidak baik. Terutama bagi wanita muslimah, dengan menutup auratnya dia akan lebih mulia di hadapan Allah dan manusia; Ketiga, menjauhi perbuatan zina. Zina merupakan perbuatan yang tercela. Allah swt. melarang mendekati perbuatan zina, karena merupakan seburukburuknya jalan. Dan hanya hamba-hamba Allah yang bertakwa sajalah yang akan mampu menjauhi perbuatan zina; Keempat, memiliki sikap rendah hati. Kerendahan hati nabi Yusuf as. telah mengantarkannya kepada derajat yang tinggi. Siapa saja yang tawadu, maka Allah akan mengantarkannya menuju derajat yang tinggi.

Ada beberapa saran yang perlu disampaikan dalam skripsi ini, yaitu: Pertama, kisah Nabi Yusuf merupakan kisah yang mengandung hikmah yang penting untuk diajarkan kepada anak didik. Sekolah dan keluarga harus mampu mengajarkan dan menanamkan etika yang terdapat dalam kisah Nabi Yusuf kepada anak didik agar tercipta generasi yang beretika dan berakhlak mulia; Kedua, terselesaikannya penelitian ini tidak menafikan adanya kekurangan dan kelemahan. Baik dari aspek analisis, maupun banyaknya ayat yang dibahas sehingga pembahasan kurang terfokuskan. Kekurangan-kekurangan yang terdapat dalam penelitian ini hendaknya dapat dikembangkan lebih lanjut; Ketiga, pada penelitian-penelitian berikutnya sebagai upaya mengembangkan khazanah penafsiran al-Qur'an. 


\section{DAFTAR PUSTAKA}

A, Muhammad Z. Ku Pilih Taat. Guepedia, 2019.

A. Nasir, Salihun. Peranan Pendidikan Agama Terhadap Pemecahan Problema Remaja. Jakarta: Kalam Mulia, 2002.

Abdullah, M. Yatimin. Pengantar studi etika. Jakarta: PT RajaGrafindo Persada, 2006.

Adawy, Musthafa al-'. Fikih Akhlak. Jakarta: Qisthi Press, 2005.

Al-Baraq, Abduh. Bukan Dosa Ternyata Dosa. Yogyakarta: Penerbit Pustaka Grhatama, 2010.

Al-Ghazali, Muhammad. Berdialog Dengan Al-Qur'an; Memahami Pesan Kitab Suci Dalam Kehidupan Masa Kini. Bandung: PT. Mizan Pustaka, 1997.

Al-ghazali. Mutiara Ihya Ulumuddin. Bandung: PT Mizan Pustaka, 2008.

Ali, Abdullah Yusuf. Qur'an Terjemahan Dan Tafsirnya. Jakarta: Pustaka Firdaus, 1993.

Ali, Muhammad, and Muhammad Asrori. Psikologi Remaja. Jakarta: PT. Bumi Aksara, 2011.

An-Nahlawi, Abdurrahman. Pindidikan Islam Di Rumah Sekolah Dan Masyarakat. Cet. II. Jakarta: Gema Insani, 1996.

Arifin, Zainal. "Pendidikan multikultural-religius untuk mewujudkan karakter peserta didik yang humanis-religius." Jurnal Pendidikan Islam 1, no. 1 (January 1, 1970): 89. https://doi.org/10.14421/jpi.2011.11.89-103.

Arsana, I. Putu Jati. Etika Profesi Insinyur: Membangun Sikap Profesionalisme Sarjana Teknik. Deepublish, 2018.

Asyur, Thahir Ibnu. Tafsir At-Tahrir Wa At-Tanwir, PDF.

Asy'ari, Musa. Manusia Pembentuk Kebudayaan Dalam Al-Qur'an. Yogyakarta: Lembaga Studi Filsafat Islam, 1992.

Az-Za'balawi, M. Sayyid Muhammad. Pendidikan Remaja antara Islam E Ilmu Jiwa. Jakarta: Gema Insani, 2007.

Bertens, K. Etika. Yogyakarta: PT. Kanisius, 2013.

Bertens, Kees. Keprihatinan Moral, Telaah atas Masalah Etika. Yogyakarta: Kanisius, 2003.

Burhan, Asmawati. Buku Ajar Etika Umum. Yogyakarta: Deepublish, 2019.

Departemen Agama RI. Al-Qur'an Dan Tafsirnya. Jakarta: Pelita, 1990.

Departemen Pendidikan Nasional. Kamus Besar Bahasa Indonesia. Jakarta: Pustaka, 2005.

Faridl, Miftah. Tak Goyah Diterpa Badai. Jakarta: Gema Insani, 2006.

Fauzi, Mohammad. Akidah Akhlak. Sidoarjo: Media Ilmu, 2008.

Gymnastiar, Abdullah. Meraih Bening Hati Dengan Manajemen Qolbu. Jakarta: Gema Insani Press, 2002.

Habanakah, Rahman H. Metode Merusak Akhlak Dari Barat. Jakarta: Gema Insani, 1995.

Hamka. Tafsir Al-Azhar. Jakarta: Pustaka Panjimas, 1983. 
Hamka. Tasauf Modern. Jakarta: PT Pustaka Panjimas, 1990.

Ihsan, Masykur. "Pengaruh Terpaan Media Internet dan Pola Pergaulan terhadap Karakter Peserta Didik". 2016

Irhandayaningsih, Ana. "Peranan Pancasila dalam Menumbuhkan Kesadaran Nasionalisme Generasi Muda di Era Global,"

Jawziyyah, Ibn Qoyyim al-. Kiat Membersihkan Hati Dari Kotoran Maksiat. Jakarta: PT. Serambi Ilmu Semesta, 2008.

Kholil, Mohamad. Etika Pendidikan Islam. Yogyakarta: Titian Wacana, 2007.

Khozin. Khazanah pendidikan agama Islam. Bandung: PT Remaja Rosdakarya, 2013.

"Kisah Terbaik dalam Al-Quran: Nabi Yusuf AS." dakwatuna.com, January 28, 2013. http://www.dakwatuna.com/2013/01/28/27326/kisah-terbaik-dalam-al-qurannabi-yusuf-as/.

Maharani, Orthorita Putri, and Budi Andayani. "Hubungan Antara Dukungan Sosial Ayah dengan Penyesuaian Sosial pada Remaja Laki-laki," 2003, 13.

Maryono, and Patmi Istiana. Teknologi Informasi \& Komunikasi 1. Yogyakarta: Yudhistira Ghalia Indonesia, 2007.

Mas'ud, Hafiz Hasan. 31 Etika Gaul Islami. Bandung: Mizan, 2005.

Masy'ari, Anwar. Akhlak Al-Qur'an. Surabaya: PT. Bina Ilmu, 2007.

Monib, Mohammad. 8 Pintu Surga. Jakarta: PT. Elex Media Komputindo, 2011.

Mustika, M. Shodiq, and Rusdin S. Rauf. The Ultimate Power of Shalat Tahajud. Jakarta: QultumMedia, 2012.

Nasirudin. Pendidikan Taswuf. Semarang: Rasail Media Group, 2010.

Nata, Abudin. Akhlak Tasawuf Dan Karakter Mulia. Jakarta: PT RajaGrafindo Persada, 2018.

Priharjo, Robert. Pengantar Etika Keperawatan. Yogyakarta: Kanisius, 1995.

Qutub, Sayyid. Tafsir Fi Zhilalil Qur'an. Jakarta: Gema Insani, 2003.

Rosita, Mamik. "Membentuk Karakter Siswa Melalui Metode Kisah Qur'ani."

Fitrah: Jurnal Kajian Ilmu-ilmu Keislaman 2, no. 1 (June 1, 2016): 53. https://doi.org/10.24952/fitrah.v2i1.455.

S. Willis, Sofyan. Remaja Dan Masalahnya. Bandung: Alfabeta, 2017.

Sarwono, Sarlito Wirawan. Psikologi remaja. Jakarta: Rajawali Pers, 2016.

Shihab, M. Quraish. Tafsir Al-Misbah. Vol. 6. Jakarta: Lentera Hati, 2003.

Syarbini, Amirulloh. Doa-Doa Khusus Wanita. Jakarta: PT. Elex Media Komputindo, 2011.

Tasmara, Toto. Menuju muslim kaffah: menggali potensi diri. Jakarta: Gema Insani, 2000.

Tim Dosen PAI. Bunga Rampai Pendidikan Dalam Pendidikan Agama Islam. Yogyakarta: Deepublish, 2016.

Wahida, Besse. "Eksistensi Bahasa Arab dalam Dunia Dakwah." Al-Hikmah 9, no. 1 (December 16, 2015). https://doi.org/10.24260/al-hikmah.v9i1.89.

Zubair, Achmad Charris. Kuliah Etika. Jakarta: Rajawali Pers, 1990. 